\title{
Author Correction: Direct imaging of structural disordering and heterogeneous dynamics of fullerene molecular liquid
}

\author{
Jeongheon Choe, Yangjin Lee (D), Jungwon Park (D), Yunho Kim (1D, Chae Un Kim (1D \& Kwanpyo Kim
}

Correction to: Nature Communications https://doi.org/10.1038/s41467-019-12320-4, published online 27 September 2019.

The original version of this Article contained an error in the Acknowledgements, which was previously incorrectly given as 'This work was mainly supported by the Basic Science Research Program through the National Research Foundation of Korea (NRF2017R1A5A1014862 and NRF-2019R1C1C1003643) and grants from the Institute for Basic Science (IBS-R006-D1)'. The correct version states 'IBS-R026-D1' in place of 'IBS-R006-D1'. This has been corrected in both the PDF and HTML versions of the Article.

Published online: 14 January 2020

(c) (i) Open Access This article is licensed under a Creative Commons Attribution 4.0 International License, which permits use, sharing, adaptation, distribution and reproduction in any medium or format, as long as you give appropriate credit to the original author(s) and the source, provide a link to the Creative Commons license, and indicate if changes were made. The images or other third party material in this article are included in the article's Creative Commons license, unless indicated otherwise in a credit line to the material. If material is not included in the article's Creative Commons license and your intended use is not permitted by statutory regulation or exceeds the permitted use, you will need to obtain permission directly from the copyright holder. To view a copy of this license, visit http://creativecommons.org/licenses/by/4.0/.

(c) The Author(s) 2020 